\title{
Incidence and mortality by larynx cancer in Central and South America
}

Incidência e mortalidade por câncer de laringe

na América Central e do Sul

Incidencia y mortalidad por cáncer de laringe

en Centro y Sudamérica

\author{
Suellen Nadine de Lima Costa \\ Fábia Cheyenne Gomes de Morais Fernandes ${ }^{\mathrm{a}}$ \\ Dyego Leandro Bezerra de Souza ${ }^{b}$ \\ Héllyda de Souza Bezerrab \\ Emelynne Gabrielly de Oliveira Santos ${ }^{\mathrm{b}}$ \\ Isabelle Ribeiro Barbosa ${ }^{b}$
}

How to cite this article:

Costa SNL, Fernandes FCGM, Souza

DLB, Santos EGO, Bezerra HS, Barbosa

IR. Incidence and mortality by larynx cancer in Central and South America. Rev Gaúcha Enferm. 2021;42:e20190469. doi: https://doi.org/10.1590/19831447.2021.20190469 aniversidade Federal do Rio Grande do Norte (UFRN), Faculdade de Ciências da Saúde do Trairi. Santa Cruz, Rio Grande do Norte, Brasil.

Universidade Federal do Rio Grande do Norte (UFRN), Centro de Ciências da Saúde, Programa de Pós-graduação em Saúde Coletiva. Natal, Rio Grande do Norte, Brasil.

\section{ABSTRACT}

Objective: To describe how the incidence and mortality trends for laryngeal cancer in South and Central American countries.

Methods: Time series study, with incidence data from the International Agency for Research on Cancer, from 1990 to 2012 and mortality data from 17 countries of the World Health Organization, from 1995 to 2013. The trend was analyzed by Joinpoint regression. Results: The highest incidence rate for laryngeal cancer was in Brazil, with 5.9 new cases per 100,000 men, and the highest mortality rate in Uruguay with 4.2 deaths per 100,000 men. The incidence ratio between genders ranged from 4: 1 (Colombia) to 12: 1 (Ecuador). The mortality ratio between the sexes ranged from 4: 1 (Peru) to 14: 1 (Uruguay).

Conclusion: Most countries had low incidence rates and reduced mortality in Latin America. Keywords: Laryngeal neoplasms. Incidence. Mortality. Laryngeal neoplasms/epidemiology.

\section{RESUMO}

Objetivo: Descrever as tendências da incidência e mortalidade para o câncer de laringe em países da América do sul e central. Métodos: Estudo de série temporal, com dados de incidência da Agência Internacional para Pesquisa do Câncer, no período de 19902012 e dados de mortalidade de 17 países da Organização Mundial da Saúde, no período de 1995-2013. A tendência foi analisada pela regressão Joinpoint.

Resultados: A taxa de incidência mais elevada para o câncer de laringe foi no Brasil, com 5,9 casos novos por 100.000 homens, e a taxa de mortalidade mais elevada foi no Uruguai com 4,2 óbitos por 100.000 homens. A razão de incidência entre os sexos variou de 4:1 (Colômbia) até 12:1 (Equador). A razão de mortalidade entre os sexos variou de 4:1 (Peru) a 14:1 (Uruguai).

Conclusão: A maioria dos países apresentou baixas taxas de incidência e redução de mortalidade na América Latina.

Palavras-chave: Neoplasias laríngeas. Incidência. Mortalidade. Neoplasias laríngeas/epidemiologia

\section{RESUMEN}

Objetivo: Describir cómo tendencias de incidencia y mortalidad por cáncer de laringe en países de América del Sur y Central.

Métodos: Estudio de series temporales, con datos de incidencia de Agencia Internacional de Investigación sobre el Cáncer, de 1990 a 2012 y datos de mortalidad de 17 países de Organización Mundial de Salud, de 1995 a 2013. La tendencia se analizó mediante regresión de Joinpoint

Resultados: La tasa de incidencia más alta para el cáncer de laringe fue en Brasil, con 5.9 casos nuevos por cada 100,000 hombres, y tasa de mortalidad más alta en Uruguay con 4.2 muertes por cada 100,000 hombres. La razón de incidencia entre géneros varió de 4: 1 (Colombia) a 12: 1 (Ecuador). La razón de mortalidad entre los sexos varió de 4: 1 (Perú) a 14: 1 (Uruguay). Conclusión: La mayoría de países tenían tasas de incidencia bajas y mortalidad reducida en América Latina. Palabras clave: Neoplasias laríngeas. Incidencia. Mortalidad. Neoplasias laríngeas/epidemiologia. 


\section{口INTRODUCTION}

Laryngeal malignancy is the most common cancer of the head and neck region, and one of the most common tumors of the respiratory tract. Although it accounts for only $1 \%$ of all cancer cases in the world, the estimate in 2018 was for 177,422 new cases of laryngeal cancer and 94,771 deaths from this disease. This cancer occurs more commonly in men than in women, with higher mortality rates in the less developed regions of the world, incidence rates of 3.6 cases per 100,000 men, 0.5 cases per 100,000 women, and mortality rates of 1.9 deaths per 100 thousand men and 0.3 deaths per 100 thousand women ${ }^{(1)}$.

The Caribbean, Central and Eastern Europe (7.9 per 100,000 inhabitants), Southern Europe (7.2) and Western Asia (6.5 per 100,000 inhabitants) record the highest incidence rate for men while South Africa, the Caribbean, North America and Western Asia (0.9 cases per 100,000 inhabitants) (2) record the highest rate for women.

Cancer control has become a major challenge for South and Central America. Regional estimates indicate, 1 million new cases of cancer and 500,000 deaths from cancer are registered annually, and projections show that these numbers may double by the year 2030. In this context, laryngeal cancer stands out for presenting different patterns of incidence and mortality between countries, in addition to a drastic proportion between genders ${ }^{(3)}$.

The use of cigarettes and alcohol are factors that substantially increase the chances of developing this neoplasm. In addition, the role of Human Papilloma Virus (HPV) infections in the carcinogenesis of laryngeal tumor ${ }^{(1)}$ has recently been discussed. Some systematic reviews and meta-analysis also show a strong association between laryngeal cancer and the presence of gastroesophageal reflux ${ }^{(4)}$, coffee intake consumption, alcohol intake and environmental factors ${ }^{(5)}$. On the other hand, adherence to healthy eating patterns is seen as a protective factor against laryngeal cancer ${ }^{(4)}$.

Latin America and the Caribbean represent 31 nations. With 600 million inhabitants and 10\% of the world population, it is a region in transition, with developing countries that present intense internal inequalities. Based on the demographic and epidemiological transition processes experienced in the last decades, these countries showed considerable changes in the structure of their populations, with consequent population aging and an increase in the burden of chronic non-communicable diseases, such as cancer(6).

The increase in the incidence of cancer in Latin America, accompanied by disproportionately high mortality rates when compared to other regions of the world, reveals the magnitude of the challenge to be faced by these countries.
Cancer control strategies in this region include issues such as the organization and development of health services, the allocation of necessary resources, the formulation of policies and programs, adapting strategies for the control of cancer and its risk factors in each country ${ }^{(6)}$.

Thus, in order to understand the behavior of laryngeal cancer in Latin America, it is necessary to describe the burden of this pathology, in an attempt to obtain results that support the work of nursing in health promotion and disease prevention in health services, also collaborating for cancer policy and control planning. Therefore, the question is: what are the trends in incidence and mortality for laryngeal cancer in Central and South American countries? Thus, the aim of this study was to describe trends in the incidence and mortality from laryngeal cancer in Central and South American countries.

\section{METHODS}

This is an ecological time series study, based on secondary data available in the databases of the International Agency for Research on Cancer (IARC) and the World Health Organization $(\mathrm{WHO})^{(7)}$. Data were collected in March 2019. The study analyzes trends in the incidence and mortality of malignant neoplasm of the larynx in Latin American countries.

As for the collection strategy, incident cases of malignant laryngeal neoplasia within a 22 year period (1990-2012) were extracted from the Cancer Incidence in Five Continents - Cl5 PLUS, which included five Population-Based Cancer Registries : four regional registries, Cali (Colombia), Goiânia (Brazil), Quito (Ecuador) and Valdivia (Chile), and one national registry, from Costa Rica. For the mortality data, the analysis contemplated the information available from 17 countries in Latin America, which represented about 90\% of the population of that region between 1995 to 2013. The years used in the study were chosen according to the availability of the IARC database, with 2013 being the last year available in the system.

The number of cases was extracted and the specific rates adjusted for age were calculated for three age groups (0-39, 40-59 and 60-74) and for the set of all ages. Specific age-adjusted rates were calculated using the standard world population, according to sex and countries with available data. The age groups were chosen using the incidence of cases based on the literature studied, with the lowest incidence being 0 to 39 years old, the age group 40 to 59 years presenting higher onset, and 60 to 74 years old being the age group that is included the elderly. The age group of people over 75 years was removed from the study, since the population at that age is small in Latin America, thus causing an 
error in the incidence and mortality rates. However, all cases and all age groups were included for the total calculation.

Incidence rates and standardized mortality rates were calculated by sex. The ratio of incidence and mortality rates by sex and age group were also calculated. In the time trend analysis, the average annual percentage change (AAPC) was estimated for incidence and mortality with a 95\% confidence interval $(95 \% \mathrm{Cl})$ in the period. The AAPC is calculated based on the accumulated geometric average of the trends in the variation of the annual percentage, with equal weights for the lengths of each segment during the fixed interval ${ }^{(8)}$. The exceptions to these analyzes, due to the lack of cases in the historical series, were the age group 0 to 39 years old for incidence, in both sexes, and for mortality, in Belize. Initially, the data were organized in Excel program spreadsheets, and later they were taken to the Joinpoint Regression Program software, version 4.5.0.0, in which the statistical analyzes and construction of the tables was completed.

As for the ethical principles of research, according to the National Research Ethics Commission (CONEP), research restricted to public domain data that does not identify the research participants, or studies limited to bibliographic review, without involving human beings, does not need approval by the CEP/CONEP System.

\section{RESULTS}

Between 1990 and 2012, the highest incidence rates for laryngeal cancer were observed in Brazil, with 5.9 and 1.1 new cases per 100,000 inhabitants, for men and women, respectively. For all countries analyzed, the incidence was higher for the 60 to 74 age group. The incidence ratio between the sexes varied from 4: 1 (Colombia) to 12:1 (Ecuador) (Table 1).

Trends in decreasing incidence of laryngeal cancer were seen in Cali (Colombia), in the total age group for males (AAPC: $-1.7 \%$ - 95\% -8.4; -3.4) and female (AAPC: - $4.0 \%-95 \%$ $-7.6 ;-3.0$ ), as well as in the $40-59$ age group (AAPC: $-5.9 \%$ 95\% -8.4; -3.4), female; and in Goiânia (Brazil), between 40-59 years (AAPC: -3.8\% - 95\% -7.4; -0.1), for females. There was a downward trend, although not significant, for the other age groups in both sexes (Table 1).

Between 1995 and 2013, the highest mortality rates from laryngeal cancer were observed in Uruguay and Argentina. The mortality ratio between the sexes ranged from 4: 1 (Peru) to 14: 1 (Uruguay) (Table 2).

There was a tendency to reduce mortality from laryngeal cancer in most countries, with emphasis on Ecuador, among women, in the total age group (AAPC: - 10.47\% - 95\% -14.73;
-5.98) and Colombia, for males, between 0-39 years (AAPC: $-6.99 \%-95 \%-12.39 ;-1.27)$, with the largest reductions. In the age group from 60 to 74 years, for females, there was stability in mortality in Argentina, Brazil and Chile. For males, Brazil, El Salvador, Guatemala, Nicaragua, Panama, Paraguay and Peru showed a stability trend. Belize did not present enough data for the analysis of the mortality history series (Table 3 ).

\section{口DISCUSSION}

The main findings of this study show that there is a general tendency to reduce the incidence and mortality from laryngeal cancer in Latin America, for both sexes and in all studied age groups. One of the most outstanding findings is the high ratio between genders, both for incidence and mortality, presented by countries such as Ecuador, Chile, Panama, Brazil and Uruguay.

The trend towards a reduction in laryngeal cancer incidence and mortality rates in this region of the planet can be confirmed by the findings of other population-based studies $^{(1,7)}$. A study in Latin America showed that the incidence of laryngeal cancer in Argentina, Brazil, Chile and Costa Rica tends to decrease for males ${ }^{(3)}$. The study by Holguin et al. (2016), shows that, in Cali, Colombia, from 1962 to 2012, the incidence for this cancer showed a reduction trend for both sexes, and that this reduction was more accentuated for males (APC $=-1.1 ; 95 \%$ Cl: $-3.6-1.5)^{(9)}$. In Quito (Ecuador), the study by Corral et al. (2018) showed an incidence stability trend for males, between 1985 to 2013 (APC $=-0.1$; 95\% Cl: $-1.9 ; 1.7)^{(10)}$.

Although the Latin American countries have a profile of mortality reduction or stability, it is necessary to consider the differences that some countries may have in incidence and mortality rates between their regions. According to the study of temporal trends that analyzed mortality in the period from 1996 to 2010, Brazil, a country with continental dimensions and evident social inequalities between its regions, showed a tendency of increasing mortality in the North and Northeast regions, for both countries. sexes, although the mortality trend for Brazil has been decreasing ${ }^{(11)}$.

Changes in incidence and mortality rates for a specific type of cancer, in a defined population, can be explained by: changes in the risk factor profile that can increase incidence and, consequently, mortality; the existence and effectiveness of screening programs and improvements and advances in treatments ${ }^{(12)}$. These three aspects could explain the incidence and mortality rates of laryngeal cancer observed for the countries of Latin America in this present study. 
Table 1 - Standardized incidence rate by age (ASIR) per 100,000 inhabitants, number of cases (N), average annual percentage change (AAPC) and Incidence ratio (SIR) for laryngeal cancer, according to age and sex, in Cali (Colombia), Costa Rica, Goiânia (Brazil), Quito (Ecuador) and Valdivia (Chile), for the period 1990-2012

\begin{tabular}{|c|c|c|c|c|c|c|c|}
\hline \multirow{2}{*}{$\begin{array}{l}\text { Population-based } \\
\text { Cancer Registry }\end{array}$} & \multirow{2}{*}{$\begin{array}{c}\text { Data } \\
\text { availability }\end{array}$} & \multirow{2}{*}{$\begin{array}{l}\text { Age } \\
\text { Groups }\end{array}$} & \multicolumn{2}{|c|}{ Male } & \multicolumn{2}{|c|}{ Female } & \multirow[b]{2}{*}{ SIR } \\
\hline & & & ASIR (N) & $\begin{array}{c}\text { AAPC } \\
\text { (CI 95\%) }\end{array}$ & ASIR (N) & $\begin{array}{c}\text { AAPC } \\
\text { (CI 95\%) }\end{array}$ & \\
\hline \multirow{4}{*}{ Cali (Colombia) } & \multirow{4}{*}{ 1990-2012 } & $0-39$ & $0,1(21)$ & - & $0,0(4)$ & - & - \\
\hline & & $40-59$ & 4,6 (173) & $-1,5(-4,5 ; 1,6)$ & $0,8(36)$ & $-5,9 *(-8,4 ;-3,4)$ & 5,75 \\
\hline & & $60-74$ & $28,2(355)$ & $-1,4(-3,0 ; 0,3)$ & $5,2(85)$ & $-3,3(-6,9 ; 0,5)$ & 5,40 \\
\hline & & Total & $3,7(549)$ & $-1,7^{*}(-2,8 ;-0,5)$ & $0,7(125)$ & $-4,0 *(-7,6 ;-0,3)$ & 5,30 \\
\hline \multirow{4}{*}{ Costa Rica } & \multirow{4}{*}{ 1990-2011 } & $0-39$ & $0,1(23)$ & - & $0,0(6)$ & - & - \\
\hline & & $40-59$ & $3,4(257)$ & $-0,7(-2,8 ; 1,4)$ & $0,4(31)$ & $-5,5(-15,1 ; 5,2)$ & 8,50 \\
\hline & & $60-74$ & $18,4(452)$ & $-0,7(-2,6 ; 1,3)$ & $1,8(44)$ & $-3,8(-7,9 ; 0,4)$ & 10,22 \\
\hline & & Total & $2,5(732)$ & $-0,7(-2,1 ; 0,7)$ & $0,3(81)$ & $-3,4(-8,0 ; 1,4)$ & 8,30 \\
\hline \multirow{4}{*}{ Goiania (Brazil) } & \multirow{4}{*}{ 1993-2012 } & $0-39$ & $0,1(12)$ & - & $0,0(3)$ & - & - \\
\hline & & $40-59$ & $11,2(220)$ & $-1,7(-4,8 ; 1,5)$ & $2,5(57)$ & $-3,8^{*}(-7,4 ;-0,1)$ & 4,50 \\
\hline & & $60-74$ & $37,4(213)$ & $-1,6(-4,5 ; 1,3)$ & $5,9(43)$ & $-2,0(-4,4 ; 0,5)$ & 6,30 \\
\hline & & Total & $5,9(445)$ & $-1,7(-4,2 ; 0,8)$ & 1,1 (103) & $-1,4(-6,3 ; 3,7)$ & 5,36 \\
\hline \multirow{4}{*}{ Quito (Ecuador) } & \multirow{4}{*}{ 1990-2012 } & $0-39$ & $0,0(2)$ & - & $0,0(2)$ & - & - \\
\hline & & $40-59$ & 1,5 (39) & $0,4(-3,1 ; 4.1)$ & $0,3(8)$ & - & 5,00 \\
\hline & & $60-74$ & 9,2 (78) & $-0.2(-3,7 ; 3.5)$ & $0,7(7)$ & - & 13,10 \\
\hline & & Total & 1,2 (119) & $-0.0(-3,7 ; 3.8)$ & $0,1(17)$ & - & 12,00 \\
\hline \multirow{4}{*}{$\begin{array}{c}\text { Valdivia } \\
\text { (Chile) }\end{array}$} & \multirow{4}{*}{ 1998-2012 } & $0-39$ & - & - & - & - & - \\
\hline & & $40-59$ & $2.0(13)$ & $-1,8(-5,5 ; 2.1)$ & $0,2(1)$ & - & 10,00 \\
\hline & & $60-74$ & $7,2(18)$ & - & $0,4(1)$ & - & 18,00 \\
\hline & & Total & $1,1(31)$ & $-5,6(-11,5 ; 0,7)$ & $0,1(2)$ & - & 11,00 \\
\hline
\end{tabular}

Fonte: $\operatorname{IARC}(7)$.

Value expressed in Cl: $95 \%$ 
Table 2 - Age-standardized mortality rate (ASMR) per 100,000 inhabitants, number (N) of deaths and Mortality Rate Ratio (SMR) for laryngeal cancer, by sex and age group, for 17 Latin American populations

\begin{tabular}{|c|c|c|c|c|c|}
\hline \multirow{2}{*}{ Population } & \multirow{2}{*}{ Data availability } & \multirow{2}{*}{ Age Groups (years) } & \multicolumn{2}{|c|}{ ASMR (N) } & \multirow{2}{*}{ SRM } \\
\hline & & & Male & Female & \\
\hline \multirow{4}{*}{ Argentina } & \multirow{4}{*}{$1997-2013$} & $0-39$ & $0,0(75)$ & $0,0(20)$ & - \\
\hline & & $40-59$ & $5,7(3973)$ & $0,5(400)$ & 11,4 \\
\hline & & $60-74$ & $22,5(6565)$ & $1,9(697)$ & 11,8 \\
\hline & & Total & $3,3(10613)$ & $0,3(1117)$ & 11,0 \\
\hline \multirow{4}{*}{ Belize } & \multirow{4}{*}{$1997-2013$} & $0-39$ & - & $0,0(1)$ & - \\
\hline & & $40-59$ & $5,3(17)$ & $2,0(6)$ & 2,6 \\
\hline & & $60-74$ & $8,0(8)$ & $2,0(2)$ & 4,0 \\
\hline & & Total & $1,9(25)$ & $0,2(3)$ & 9,5 \\
\hline \multirow{4}{*}{ Brazil } & \multirow{4}{*}{ 1996-2013 } & $0-39$ & $0,1(711)$ & $0,0(180)$ & - \\
\hline & & $40-59$ & $6,3(20121)$ & $0,6(2124)$ & 10,5 \\
\hline & & $60-74$ & $20,0(20625)$ & $2,2(2742)$ & 9,1 \\
\hline & & Total & $3,2(41457)$ & $0,3(5046)$ & 10,6 \\
\hline \multirow{4}{*}{ Chile } & \multirow{4}{*}{ 1997-2013 } & $0-39$ & $0,0(12)$ & $0,0(3)$ & - \\
\hline & & $40-59$ & 1,1(336) & $0,1(46)$ & 11,0 \\
\hline & & $60-74$ & $8,1(906)$ & $0,9(126)$ & 9,0 \\
\hline & & Total & $1,0(1254)$ & $0,1(175)$ & 10,0 \\
\hline \multirow{4}{*}{ Colombia } & \multirow{4}{*}{$1997-2013$} & $0-39$ & $0,0(76)$ & $0,0(51)$ & - \\
\hline & & $40-59$ & 1,5 (996) & $0,4(280)$ & 3,8 \\
\hline & & $60-74$ & $12,1(2434)$ & $2,6(622)$ & 4,7 \\
\hline & & Total & $1,4(3506)$ & $0,3(953)$ & 4,6 \\
\hline \multirow{4}{*}{ Costa Rica } & \multirow{4}{*}{$1997-2013$} & $0-39$ & $0,0(6)$ & $0,0(2)$ & - \\
\hline & & $40-59$ & $1,5(111)$ & $0,2(13)$ & 7,5 \\
\hline & & $60-74$ & $7,9(201)$ & $0,9(25)$ & 8,7 \\
\hline & & Total & $1,1(318)$ & $0,1(40)$ & 11,0 \\
\hline \multirow{4}{*}{ Ecuador } & \multirow{4}{*}{$1997-2013$} & $0-39$ & $0,0(18)$ & $0,0(12)$ & - \\
\hline & & $40-59$ & $0,6(120)$ & $0,2(31)$ & 3,0 \\
\hline & & $60-74$ & $3,6(239)$ & $0,8(62)$ & 4,5 \\
\hline & & Total & $0,5(377)$ & $0,1(105)$ & 5,0 \\
\hline
\end{tabular}


Table 2 - Cont.

\begin{tabular}{|c|c|c|c|c|c|}
\hline \multirow{2}{*}{ Population } & \multirow{2}{*}{ Data availability } & \multirow{2}{*}{ Age Groups (years) } & \multicolumn{2}{|c|}{ ASMR (N) } & \multirow{2}{*}{ SRM } \\
\hline & & & Male & Female & \\
\hline \multirow{4}{*}{ El Salvador } & \multirow{4}{*}{$1997-2013$} & $0-39$ & $0,0(9)$ & $0,0(4)$ & - \\
\hline & & $40-59$ & $0,7(55)$ & $0,2(19)$ & 3,5 \\
\hline & & $60-74$ & $3,5(113)$ & $0,6(24)$ & 5,9 \\
\hline & & Total & $0,5(177)$ & $0,1(47)$ & 5,0 \\
\hline \multirow{4}{*}{ Guatemala } & \multirow{4}{*}{$2000-2013$} & $0-39$ & $0,0(29)$ & $0,0(20)$ & - \\
\hline & & $40-59$ & $0,9(97)$ & $0,3(42)$ & 3,0 \\
\hline & & $60-74$ & $4,3(185)$ & $1,0(51)$ & 4,3 \\
\hline & & Total & $0,6(311)$ & $0,2(113)$ & 3,0 \\
\hline \multirow{4}{*}{ Mexico } & \multirow{4}{*}{$1998-2013$} & $0-39$ & $0,0(165)$ & $0,0(74)$ & - \\
\hline & & $40-59$ & $1,5(2178)$ & $0,2(343)$ & 7,5 \\
\hline & & $60-74$ & $10,2(4983)$ & $1,4(754)$ & 7,4 \\
\hline & & Total & $1,3(7326)$ & $0,2(1171)$ & 6,5 \\
\hline \multirow{4}{*}{ Nicaragua } & \multirow{4}{*}{$1997-2013$} & $0-39$ & $0,0(8)$ & $0,0(5)$ & - \\
\hline & & $40-59$ & $1,4(83)$ & $0,2(16)$ & 7,0 \\
\hline & & $60-74$ & $6,3(124)$ & $1,0(23)$ & 6,3 \\
\hline & & Total & $0,9(215)$ & $0,2(44)$ & 4,5 \\
\hline \multirow{4}{*}{ Panama } & \multirow{4}{*}{$1998-2013$} & $0-39$ & $0,0(3)$ & $0,1(20)$ & 0,0 \\
\hline & & $40-59$ & $1,5(72)$ & $0,2(8)$ & 7,5 \\
\hline & & $60-74$ & $8,5(146)$ & $0,5(9)$ & 17,0 \\
\hline & & Total & $1,1(221)$ & $0,1(17)$ & 11,0 \\
\hline \multirow{4}{*}{ Paraguay } & \multirow{4}{*}{$1996-2013$} & $0-39$ & $0,0(12)$ & - & - \\
\hline & & $40-59$ & $2,1(174)$ & - & - \\
\hline & & $60-74$ & $8,8(241)$ & - & - \\
\hline & & Total & $1,3(427)$ & - & - \\
\hline \multirow{4}{*}{ Peru } & \multirow{4}{*}{ 1999-2013 } & $0-39$ & $0,0(32)$ & $0,0(23)$ & - \\
\hline & & $40-59$ & $0,4(132)$ & $0,1(53)$ & 4,0 \\
\hline & & $60-74$ & $3,0(387)$ & $0,7(90)$ & 4,2 \\
\hline & & Total & $0,4(551)$ & $0,1(166)$ & 4,0 \\
\hline
\end{tabular}


Table 2 - Cont.

\begin{tabular}{|c|c|c|c|c|c|}
\hline \multirow{2}{*}{ Population } & \multirow{2}{*}{ Data availability } & \multirow{2}{*}{ Age Groups (years) } & \multicolumn{2}{|c|}{ ASMR (N) } & \multirow{2}{*}{ SRM } \\
\hline & & & Male & Female & \\
\hline \multirow{4}{*}{ Suriname } & \multirow{4}{*}{ 1995-2013 } & $0-39$ & $0,2(6)$ & $0,3(10)$ & 0,6 \\
\hline & & $40-59$ & $0,4(3)$ & $0,1(1)$ & 4,0 \\
\hline & & $60-74$ & $3,4(10)$ & $0,9(3)$ & 3,7 \\
\hline & & Total & $0,4(13)$ & $0,1(4)$ & 4,0 \\
\hline \multirow{4}{*}{ Uruguay } & \multirow{4}{*}{$1997-2013$} & $0-39$ & $0,0(8)$ & $0,0(1)$ & - \\
\hline & & $40-59$ & $6,3(379)$ & $0,4(24)$ & 15,8 \\
\hline & & $60-74$ & $30,2(854)$ & $1,9(69)$ & 16,0 \\
\hline & & Total & $4,2(1241)$ & $0,3(94)$ & 14,0 \\
\hline \multirow{4}{*}{ Venezuela } & \multirow{4}{*}{$1996-2013$} & $0-39$ & $0,0(89)$ & $0,0(35)$ & - \\
\hline & & $40-59$ & $3,8(1554)$ & $0,5(223)$ & 7,6 \\
\hline & & $60-74$ & $18,0(2328)$ & $2,4(354)$ & 7,5 \\
\hline & & Total & $2,5(3971)$ & $0,3(612)$ & 8,3 \\
\hline
\end{tabular}

Source: $\operatorname{AR}(\nabla)$.

Table 3 - Trends in mortality from laryngeal cancer per 100,000 inhabitants, by sex and age group, for 14 Latin American populations, from 1995 to 2013

\begin{tabular}{|c|c|c|c|c|}
\hline \multirow{2}{*}{ Population } & \multirow{2}{*}{ Data availability } & \multirow{2}{*}{ Age Groups } & \multicolumn{2}{|c|}{ AAPC (Cl 95\%) } \\
\hline & & & Male & Female \\
\hline \multirow{4}{*}{ Argentina } & \multirow{4}{*}{$1997-2013$} & $0-39$ & - & - \\
\hline & & $40-59$ & $-5,75(-6,42 ;-5,07)$ & $-1,30(-3,34 ; 0,79)$ \\
\hline & & $60-74$ & $-2,58(-3,01 ;-2,15)$ & $1,51(-0,03 ; 3,08)$ \\
\hline & & Total & $-3,75(-4,06 ;-3,44)$ & $0,06(-1,05 ; 1,19)$ \\
\hline \multirow{4}{*}{ Brazil } & \multirow{4}{*}{$1996-2013$} & $0-39$ & $-1,60(-3,28 ; 0,10)$ & $-0,09(-4,55 ; 4,59)$ \\
\hline & & $40-59$ & $-0,13(-0,50 ; 0,24)$ & $0,18(-0,75 ; 1,13)$ \\
\hline & & $60-74$ & $-0,40(-0,84 ; 0,03)$ & $-0,28(-1,25 ; 0,71)$ \\
\hline & & Total & $-0,31(-0,68 ; 0,07)$ & $-0,12(-0,87 ; 0,63)$ \\
\hline \multirow{4}{*}{ Chile } & \multirow{4}{*}{$1997-2013$} & $0-39$ & - & - \\
\hline & & $40-59$ & $-1,59(-3,33 ; 0,17)$ & $-2,03(-6,97 ; 3,16)$ \\
\hline & & $60-74$ & $-3,68(-4,53 ;-2,81)$ & $-1,00(-5,62 ; 3,84)$ \\
\hline & & Total & $-3,22(-3,99 ;-2,45)$ & $-1,87(-4,86 ; 1,21)$ \\
\hline
\end{tabular}


Table 3 - Cont.

\begin{tabular}{|c|c|c|c|c|}
\hline \multirow{2}{*}{ Population } & \multirow{2}{*}{ Data availability } & \multirow{2}{*}{ Age Groups } & \multicolumn{2}{|c|}{ AAPC (CI 95\%) } \\
\hline & & & Male & Female \\
\hline \multirow{4}{*}{ Colombia } & \multirow{4}{*}{ 1997-2013 } & $0-39$ & $-6,99(-12,39 ;-1,27)$ & - \\
\hline & & $40-59$ & $-5,98(-7,07 ;-4,89)$ & $-7,45(-9,43 ;-5,44)$ \\
\hline & & $60-74$ & $-4,29(-5,37 ;-3,20)$ & $-7,63(-9,46 ;-5,76)$ \\
\hline & & Total & $-4,70(-5,70 ;-3,68)$ & $-7,57(-9,01 ;-6,11)$ \\
\hline \multirow{4}{*}{ Costa Rica } & \multirow{4}{*}{$1997-2013$} & $0-39$ & - & - \\
\hline & & $40-59$ & $2,94(-2,31 ; 8,47)$ & - \\
\hline & & $60-74$ & $-5,41(-8,83 ;-1,86)$ & - \\
\hline & & Total & $-3,37(-5,62 ;-1,06)$ & - \\
\hline \multirow{4}{*}{ Ecuador } & \multirow{4}{*}{$1997-2013$} & $0-39$ & - & - \\
\hline & & $40-59$ & $-1,03(-6,65 ; 4,93)$ & - \\
\hline & & $60-74$ & $-2,99 *(-5,43 ;-0,49)$ & $-10,44(-15,60 ;-4,95)$ \\
\hline & & Total & $-2,91 *(-4,75 ;-1,03)$ & $-10,47(-14,73 ;-5,98)$ \\
\hline \multirow{4}{*}{ El Salvador } & \multirow{4}{*}{$1997-2013$} & $0-39$ & - & - \\
\hline & & $40-59$ & - & - \\
\hline & & $60-74$ & $2,61(-3,06 ; 8,61)$ & - \\
\hline & & Total & $5,14(-0,64 ; 11,27)$ & - \\
\hline \multirow{4}{*}{ Guatemala } & \multirow{4}{*}{$2000-2013$} & $0-39$ & - & - \\
\hline & & $40-59$ & $1,28(-3,94 ; 6,77)$ & $-0,36(-7,33 ; 7,13)$ \\
\hline & & $60-74$ & $0,81(-2,24 ; 3,95)$ & - \\
\hline & & Total & $0,59(-1,63 ; 2,87)$ & $4,38(-2,43 ; 11,67)$ \\
\hline \multirow{4}{*}{ Mexico } & \multirow{4}{*}{$1998-2013$} & $0-39$ & $-4,27^{*}(-6,98 ;-1,48)$ & $-9,34^{*}(-14,91 ;-3,41)$ \\
\hline & & $40-59$ & $-3,74^{*}(-4,76 ;-2,71)$ & $-7,70(-10,45 ;-4,86)$ \\
\hline & & $60-74$ & $-3,73^{*}(-4,20 ;-3,26)$ & $-5,16^{*}(-6,40 ;-3,90)$ \\
\hline & & Total & $-3,73^{*}(-4,24 ;-3,22)$ & $-6,05^{*}(-6,97 ;-5,12)$ \\
\hline \multirow{4}{*}{ Nicaragua } & \multirow{4}{*}{$1997-2013$} & $0-39$ & - & - \\
\hline & & $40-59$ & $0,05(-4,95 ; 5,31)$ & - \\
\hline & & $60-74$ & $0,88(-3,27 ; 5,22)$ & - \\
\hline & & Total & $0,31(-3,02 ; 3,75)$ & - \\
\hline
\end{tabular}


Table 3 - Cont.

\begin{tabular}{|c|c|c|c|c|}
\hline \multirow{2}{*}{ Population } & \multirow{2}{*}{ Data availability } & \multirow{2}{*}{ Age Groups } & \multicolumn{2}{|c|}{ AAPC (CI 95\%) } \\
\hline & & & Male & Female \\
\hline \multirow{4}{*}{ Panama } & \multirow{4}{*}{$1998-2013$} & $0-39$ & - & - \\
\hline & & $40-59$ & $-1,63(-5,34 ; 2,22)$ & - \\
\hline & & $60-74$ & $-0,31(-3,98 ; 3,49)$ & - \\
\hline & & Total & $-1,15(-4,15 ; 1,95)$ & - \\
\hline \multirow{4}{*}{ Paraguay } & \multirow{4}{*}{$1996-2013$} & $0-39$ & - & - \\
\hline & & $40-59$ & $4,21(-0,63 ; 9,29)$ & - \\
\hline & & $60-74$ & $-0,86(-3,48 ; 1,84)$ & - \\
\hline & & Total & $0,63(-1,63 ; 2,94)$ & - \\
\hline \multirow{4}{*}{ Peru } & \multirow{4}{*}{ 1999-2013 } & $0-39$ & - & - \\
\hline & & $40-59$ & $-1,01(-5,90 ; 4,13)$ & - \\
\hline & & $60-74$ & $-2,49(-5,34 ; 0,44)$ & $-5,66^{*}(-10,30 ;-0,78)$ \\
\hline & & Total & $-2,34(-4,71 ; 0,09)$ & $-1,38(-5,91 ; 3,37)$ \\
\hline \multirow{4}{*}{ Venezuela } & \multirow{4}{*}{$1996-2013$} & $0-39$ & $-3,06(-7,42 ; 1,50)$ & $-3,27(-7,51 ; 1,16)$ \\
\hline & & $40-59$ & $-2,26^{*}(-3,27 ;-1,24)$ & $-2,95(-5,97 ; 0,17)$ \\
\hline & & $60-74$ & $-0,68^{*}(-1,27 ;-0,09)$ & $-3,21^{*}(-4,81 ;-1,59)$ \\
\hline & & Total & $-1,21 *(-1,74 ;-0,67)$ & $-3,21^{*}(-4,49 ;-1,90)$ \\
\hline
\end{tabular}

Source: $\operatorname{IARC}(7)$

Value expressed in Cl: $95 \%$

In relation to risk factors related to laryngeal cancer, smoking and alcohol consumption have been changing in recent decades. The region of the Americas has a prevalence of 18.7\% of cigarette consumption, registering a higher prevalence of use between the years 1996 to 1999. Chile and Argentina stand out, with the highest prevalence (around 40\%), and the lowest percentages in Peru (22\%). Differences are also expressed in relation to gender: the prevalence of smoking in males was 13\% in Barbados and 54.7\% in Cuba. For females, the prevalence was 1.1\% in Barbados and 37.5\% in Chile ${ }^{(8.13)}$.

In Brazil, smoking among adults over 18 years old showed a significant reduction, observed by the 1989 percentages in men, with $43.3 \%$, and women, $27.0 \%$, compared to 2013 , with $18.9 \%$ and $11.0 \%$, in men and women, respectively. It is estimated that there was a $46 \%$ decrease in smokers in the country between 1989 and 2010, with avoided around
420,000 deaths, due to the implementation of Tobacco Control Policies ${ }^{(14)}$.

Cultural and religious aspects influence gender differences in tobacco use, resulting in smoking prevalence rates of less than $2 \%$ in women, while prevalence rates among men are above $30 \%$. Considering the world as regions such as Africa, the Americas and Europe, there was a trend towards lower tobacco consumption among women. This behavior is due to the fact that the use of tobacco was first introduced among men, associated with the combined idea of glamor and masculinity; only later did consumption of the product reach the female audience, associated with factors such as gender equality ${ }^{(15)}$. The profile of smoking prevalence in Latin America may, in part, explain the tendency to reduce the observed incidence and mortality, as well as the differences between genders. 
In relation to alcoholism, worldwide, the number of cancer cases attributable to alcohol has increased by approximately 770,000 cases (5.5\% of the total number of cancer cases) - of these, 540,000 in men (7.2\% of the number total cancer cases in men) and 230,000 in women (3.5\% of the total number of cancer cases in women). Among men, approximately $60 \%$ of cancer cases attributable to alcohol were tumors of the upper aerodigestive tract (oral cavity and pharynx, esophageal and larynx ${ }^{(16)}$.

Countries in the region of the Americas has a major problem in relation to the total amount of alcohol consumed and the prevalence of heavy episodic use and disorders induced by the use of this substance, second only to the European region. Brazil exceeds the average of the Americas in relation to the annual consumption of pure alcohol per inhabitant over the age of 15, and the use of alcohol in the country is the fourth risk factor for the global disease load. There are more alcohol consumers in the higher socioeconomic groups of these countries, while abstention is greater in the less favored social groups ${ }^{(16-17)}$.

The Americas have a known differences between men and women in terms of how much they drink, how they drink, the type and alcoholic strength of the drinks they choose, and the resulting social and health consequences. It is estimated that the average consumption among men is 2 to 10 times higher than that of women ${ }^{(18)}$. These data on alcohol use in the Americas may explain the pattern of incidence of laryngeal cancer, especially among men, observed in the present study.

The main strategies for the control of smoking and alcoholism in Latin America include the Framework Convention for Tobacco Control (CQCT) and the Action Plan to Reduce Harmful Use of Alcohol, respectively, defined by the World Health Organization (WHO). The first was adopted by the countries of Central and South America, with the exception of Cuba, Argentina and El Salvador. The Action Plan has measures aimed at not driving drunk and limiting the availability of access to alcohol. Although adopted by Brazil, Suriname and Uruguay, these policies still need to improve their impact. Some countries are making efforts to prevent smoking, by increasing tax rates on tobacco products, and by disseminating information to the public on mortality from cancers associated with smoking ${ }^{(19-20)}$.

Regarding cancer screening programs, there are few reports on screening for laryngeal cancer, and this makes it difficult to assess the effectiveness of actions at the population level with the aim of reducing the incidence and mortality from this specific type of cancer ${ }^{(15)}$. Regarding treatment, this may be a crucial factor for changing the patterns of this cancer in Latin America. With a wide variety of treatments and a relatively favorable prognosis, treatment for laryngeal neoplasia shows better results in patients in the early stages of cancer. This reflects the need for preventive actions and access to health services for early diagnosis and treatment as a strategy for reducing mortality ${ }^{(19)}$.

In Latin America, health systems often have fragmented structures that provide minimal care. In addition, the current global crisis reverberates in health planning and budgeting. In addition, the unequal allocation of human resources, the concentration of health professionals in large urban centers and the lack of investment in equipment and infrastructure, all lead to the reproduction of socioeconomic inequalities in the care of individuals with cancer ${ }^{(6)}$.

This inequality highlights the scarcity of resources for the treatment and control of cancer in Latin America. The implementation and/or strengthening of tobacco and alcohol control policies, in addition to the organization of health services for early detection and treatment, is an important opportunity to reduce the laryngeal cancer load in the future.

\section{$\square$ CONCLUSION}

From the above, it was observed that laryngeal cancer has a tendency to reduce incidence and mortality for most countries in Latin America in the years studied. However, it is important to highlight that this neoplasm has high incidence rates and a higher load among males in all countries in the region.

The main risk factors for laryngeal cancer are mainly determined by the use of tobacco and alcohol. It is essential that Latin American countries strengthen measures to control these risk factors in order to reduce cases and deaths.

We emphasize the need for further research to analyze long-term data on the incidence of laryngeal cancer compared to smoking and alcoholism trends, to observe how the temporal changes in the profile of this cancer are related to these factors in Latin America.

In addition, it is essential to highlight the role of nursing in promoting health and preventing disease in relation to laryngeal cancer. The nurse has an indispensable role in the control of risk factors, such as the disclosure of policies to prevent the use of alcohol and cigarettes, vaccination against HPV, and holding a nursing consultation to encourage healthy lifestyle habits. In addition, this professional is also essential in the early detection of the disease through physical examination.

The limitation identified in this study is the possibility of underreporting. Although the number of population-based cancer registries (PBCRS) included in Cancer Incidence in Five Continents - C15 PLUS has increased in recent years, some countries still do not meet quality standards, such as Belize, which has not had its mortality trend calculated due to lack 
of registered cases. Although important advances in cancer registration have been achieved in Latin America, much remains to be done to fill the gaps in cancer surveillance, and significant improvements in data quality, coverage, and use are needed. Despite these limitations, the data used in the present study have been validated by international organizations and can be used to describe the profile of incidence and mortality in Central and South American countries.

\section{REFERENCES}

1. Bray F, Ferlay J, Soerjomataram I, Siegel RL, Torre LA, Jemal A. Global cancer statistics 2018: GLOBOCAN estimates of incidence and mortality worldwide for 36 cancers in 185 countries. CA: Cancer J Clin. 2018;68(6):394-424. doi: https://doi.org/10.3322/caac.21492

2. Ferlay J, Colombet M, Soerjomataram I, Dyba T, Randi G, Bettio M, et al. Cancer incidence and mortality patterns in Europe: estimates for 40 countries and 25 major cancers in 2018. Eur J Cancer 2018;(103):356-87. doi: https://doi. org/10.1016/j.ejca.2018.07.005

3. Sierra MS, Soerjomataram I, Antoni S, Laversanne M, Piñeros M, Vries E, et al. Cancer patterns and trends in Central and South America. Cancer Epidemiol. 2016;44(Suppl 1):S23-S42. doi: https://doi.org/10.1016/j.canep.2016.07.013

4. Parsel SM, Wu EL, Riley CA, McCoul ED. Gastroesophageal and laryngopharyngeal reflux associated with laryngeal malignancy: a systematic review and metaanalysis. Clin Gastroenterol Hepatol. 2019 17(7):1253-64. doi: https://doi. org/10.1016/j.cgh.2018.10.028

5. Chen J, Long S. Tea and coffee consumption and risk of laryngeal cancer: a systematic review meta-analysis. PLOS ONE, 2014;9(12):e112006. doi: https:// doi.org/10.1371/journal.pone.0112006

6. Bray F, Piñeros M. Cancer patterns, trends and projections in Latin America and the Caribbean:a global context.Salud Pública México, 2016 [cited 20190ct25];58(2):10417. Available from: https://scielosp.org/pdf/spm/2016.v58n2/104-117/en

7. Ferlay J, Bray F, Steliarova-Foucher E, Forman D. Cancer incidence in five continents, CI5plus. Lyon: IARC; 2014 [cited 2019 Out 10]. (IARC Cancer Base, No. 10). Available from: https://publications.iarc.fr/Databases/larc-Cancerbases/ Cancer-Incidence-In-Five-Continents-CI5plus-2014

8. Barbosa IR, Souza DL, Bernal MM, Costa ICC. Cancer mortality in Brazil: temporal trends and predictions for the year 2030. Medicine. 2015;94(16):e746. doi: https://doi.org/10.1097/MD.0000000000000746

9. Holguin JA, Urrea MF, Jimenez AM, Osorio MC, Barreto JM, Bravo LE, Collazos PA. Cáncer de laringe en Cali, Colombia, 1962-2015. Rev Colomb Cancerol. 2017;21(1):65. doi: https://doi.org/10.1016/j.rccan.2017.02.047
10. Corral CF, Cueva AP, Yepez MJ, Tarupi MW. Trends in cancer incidence and mortality over three decades in Quito - Ecuador. Colomb Med (Cali). 2018;49(1):35-41. doi: https://doi.org/10.25100/cm.v49i1.3785

11. Oliveira NPD, Barbosa IR, Paulino JNV, Cancela MC, Souza DLB. Regional and gender differences in laryngeal cancer mortality: trends and predictions until 2030 in Brazil. Oral Surg Oral Med Oral Pathol Oral Radiol. 2016;122(5):547-54. doi: https://doi.org/10.1016/j.0000.2016.06.014

12. Fagundes LGS, Martins MG, Magalhães EMS, Palmiéri PCR, Silva Júnior SI. Políticas de saúde para o controle do tabagismo na América Latina e Caribe: uma revisão integrativa. Ciênc Saúde Coletiva. 2014;19(2):499-510. doi: https://doi. org/10.1590/1413-81232014192.13482012

13. World Health Organization (CH).WHO Global report on trends in tobaccosmoking 2000-2025. $2^{\text {nd }}$ edition. Geneva:WH0; 2018 [cited 2019 0ct 10]. Available from: https://apps.who.int/iris/bitstream/handle/10665/272694/9789241514170eng.pdf?ua=1

14. Instituto Nacional do Câncer (BR) [Internet]. Rio de Janeiro: INCA; c2019-2020 [cited 2019 Sep 12]. Observatório da Política Nacional de Controle do Tabaco: dados e números da prevalência do tabagismo; [about 8 screens]. Available from: https://www.inca.gov.br/ observatorio-da-politica-nacional-de-controle-do-tabaco/dados-e-numeros

15. Malta DC, Oliveira TP, Vieira ML, Almeida L, Szwarcwald CL. Use of tobacco and exposure to tobacco smoke in Brazil: results from the National Health Survey 2013. Epidemiol Serv Saúde. 2015;24(2):239-48. doi: https://doi.org/10.5123/ S1679-49742015000200006

16. Praud D, Rota M, Rehm J, Shield K, Zatoński W, Hashibe M, et al. Cancer incidence and mortality attributable to alcohol consumption. Int J Cancer. 2016;138(6):1380-7. doi: https://doi.org/10.1002/ijc.29890

17. Machado IE, Monteiro MG, Malta DC, Lana FCF. Brazilian Health Survey (2013): relation between alcohol use and sociodemographic characteristics by sex in Brazil. Rev Brasil Epidemiol. 2017;20(3):408-22. doi: https://doi. org/10.1590/1980-5497201700030005

18. Monteiro MG. Alcohol y Salud Pública en América Latina:i cómo impedir un desastre sanitario? Adicciones. 2013;25(2):99-105. doi: https://doi. org/10.20882/adicciones.56

19. Silva TDNC, Oliveira ERRS, Costa CMC, Carlos CIC. Análise epidemiológica e da sobrevida de pacientes com carcinoma epidermoide de laringe. Rev Bras Cir Cabeça Pescoço. 2015 [citado 2019 set 10];44(2):70-7. Disponível em: http://www.sbccp.org.br/wp-content/uploads/2015/07/Rev-SBCCP-44-2artigo-05.pdf

20. Portes LH, Machado CV, Turci SRB, Figueiredo VC, Cavalcante TM, Silva VLC. Tobacco Control Policies in Brazil: a 30-year assessment. Ciênc Saúde Coletiva. 2018;23(6):1837-48. doi: https://doi. org/10.1590/1413-81232018236.05202018

\section{- Corresponding author:}

Héllyda de Souza Bezerra

E-mail: hellydasbezerra@hotmail.com

\section{Associate editor:}

Helga Geremias Gouveia 